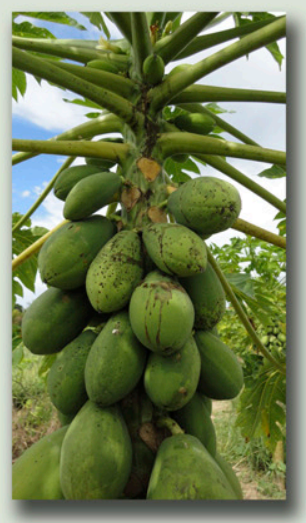

\title{
Battle of Three: The Curious Case of Papaya Sticky Disease
}

\section{Tathiana F. Sá Antunes, ${ }^{1}$ Marlonni Maurastoni, ${ }^{1}$ L. Johana Madroñero, ${ }^{1,2}$ Gabriela Fuentes, ${ }^{3}$ Jorge M. Santamaría, ${ }^{3}$ José Aires Ventura, ${ }^{4}$ Emanuel F. Abreu, ${ }^{5}$ A. Alberto R. Fernandes, ${ }^{1}$ and Patricia M. B. Fernandes ${ }^{1,}$}

\author{
${ }^{1}$ Nucleo de Biotecnologia Universidade Federal do Espírito Santo, Vitória, Espírito Santo 29040-090, Brazil \\ ${ }^{2}$ Universidad El Bosque, Vicerrectoría de Investigaciones, Bogota, Colombia \\ ${ }^{3}$ Centro de Investigación Científica de Yucatán, Col. Chuburná de Hidalgo, 97200 Mérida, Yucatán, Mexico \\ ${ }^{4}$ Instituto Capixaba de Pesquisa, Assistência Técnica e Extensão Rural, Vitória 29050790, Espírito Santo, Brazil \\ ${ }^{5}$ Embrapa Recursos Genéticos e Biotecnologia, Brasília, DF, 70770-900, Brazil
}

Keywords: papaya meleira virus, papaya meleira virus 2, virus-host interactions, pre-flowering tolerance

World papaya production is concentrated in five countries (India, Brazil, Mexico, Indonesia, and the Dominican Republic), with global estimates of over 13 million tons in 2018 (FAOSTAT 2018). Production in India, the leading producer, is mainly destined for internal consumption. Brazil is the second largest papaya producer, accounting for 1 million tons of world production (FAOSTAT 2018). Mexico plays a pivotal role as a key supplier to the U.S.A., which is the largest import market. Approximately $80 \%$ of papayas in the U.S.A. originate from Mexico (FAO 2019). Although most of the papaya produced worldwide is consumed in domestic markets, high levels of fruit export provide a significant source of income and employment year-round (FAO 2017).

Papaya diseases have diverse biotic and abiotic etiologies that affect the plant and fruit quality, causing severe economic losses. In the world's leading papaya production regions, the major diseases are caused by viruses. Although more than 10 different virus species

${ }^{\dagger}$ Corresponding author: P. M. B. Fernandes; patricia.fernandes@ufes.br

All the authors have equal contribution. All authors read and approved the manuscript.

Funding: Tathiana F. Sá Antunes and L. Johana Madronero would like to thank the Coordenação de Aperfeiçoamento de Pessoal de Nível Superior, CAPES (Ministry of Education of Brazil), and Marlonni Maurastoni thanks the Fundação de Amparo à Pesquisa do Espírito Santo - FAPES (grants 76437906/16 and 80598609/17) for their fellowship. P.M.B. Fernandes and J.A. Ventura acknowledge the Conselho Nacional de Desenvolvimento Científico e Tecnológico, CNPq for their research productivity award (grants 303432/2018-7 and 308631/2016-1). Thanks are due to Dr. Raul Tapia for providing the papaya Maradol picture presented in Fig. 1.

*The $\boldsymbol{e}$-Xtra logo stands for "electronic extra" and indicates that one supplementary figure is published online.

The author(s) declare no conflict of interest.

Accepted for publication 8 June 2020.

(C) 2020 The American Phytopathological Society have been reported in papaya worldwide (Table 1), only three present a threat to papaya cultivation in the Americas: Papaya ringspot virus (PRSV-P), Papaya mosaic virus (PapMV), and the papaya meleira virus complex, comprising papaya meleira virus $(\mathrm{PMeV})$ and papaya meleira virus 2 (PMeV2).

PRSV-P causes severe damage in the main papaya production areas of Brazil and Mexico with crop losses of up to $85 \%$. PRSV$\mathrm{P}$ is mainly transmitted by aphid species in a nonpersistent manner (Wu et al. 2018). PapMV was first reported in 1962 in Florida, U.S.A., and has spread to Bolivia, Peru, Venezuela, and Mexico (Varun et al. 2017). PRSV-P and PapMV mixed infections present a synergistic interaction that leads to increased virus accumulation and symptoms (Chávez-Calvillo et al. 2016; García-Viera et al. 2018).

Papaya sticky disease (PSD), first reported as early as 1980 in Brazil, reached Mexico in 2008 (Perez-Brito et al. 2012) and Australia in 2019 (Pathania et al. 2019). In recent years, research on the etiology of the disease (P. M. V. Abreu et al. 2015; Sá Antunes et al. 2016), transmission (García-Cámara et al. 2018, 2019; Tapia-Tussell et al. 2015), and the plant-virus interaction (Abreu et al. 2014; Madroñero et al. 2018; Soares et al. 2017) has led to significant advances in the understanding of the PSD pathosystem. Here, we review the key developments in the literature, propose an interaction map for the Carica papaya-PMeV complex, and summarize the current management strategies for PSD.

\section{Papaya Sticky Disease: Two Viruses, One Disease}

In the northeast region of Brazil, in the late 1980s, papaya began to exhibit an exudation of fluid and aqueous latex (Nakagawa et al. 1987). This was credited to boron and calcium deficiencies as the symptoms were similar to those observed on plants with these abiotic stresses (Nakagawa et al. 1987). In 1989, epidemiological studies identified a biotic pattern, which was confirmed by the appearance of disease in healthy plants inoculated with latex from diseased plants (Rodrigues et al. 1989). The sticky appearance of infected papaya fruits after the latex oxidation by exposure to the air led to the name papaya sticky disease ("meleira" in Portuguese) (Fig. 1). In Brazil, PSD is currently distributed in the northeastern states of Ceará, 
Rio Grande do Norte, Pernambuco, Bahia, and Espírito Santo (Meissner Filho et al. 2017).

Transmission electron microscopy images showed isometric particles of approximately $42 \mathrm{~nm}$ in the laticifers of diseased plants (Kitajima et al. 1993) (Supplementary Fig. S1). The purification of those particles from papaya latex and subsequent inoculation on healthy papaya seedlings that later developed typical symptoms of PSD confirmed the causal agent as a virus (Maciel-Zambolim et al. 2003).

Initially, experiments to identify the causal agents involved nucleic acid extraction of the latex tapped from papaya plants with typical symptoms of PSD (Maciel-Zambolim et al. 2003; Rodrigues et al. 2005). Total RNA was analyzed by gel electrophoresis leading to the visualization of two bands: a double-stranded RNA (dsRNA) band estimated to be either $\sim 10 \mathrm{~kb}$ (Kitajima et al. 1993) or $\sim 12 \mathrm{~kb}$ (Maciel-Zambolim et al. 2003), designated PMeV, and another thenunnoticed band of $\sim 4.5 \mathrm{~kb}$ (Sá Antunes et al. 2016).

PMeV dsRNA sequences were obtained from isolates from Espírito Santo (Sá Antunes et al. 2016) and Rio Grande do Norte (E. F. M. Abreu et al. 2015). Sequence alignment showed a high similarity between the PMeV isolates and totiviruses. This family includes viruses with a single-component dsRNA genome that infects fungi and protozoa and forms virions (Fauquet and Fargette 2005). PMeV dsRNA contains two open reading frames (ORFs) coding for a capsid protein (CP) and an RNA-dependent RNA polymerase (RdRp) (Fig. 2A) (E. F. M. Abreu et al. 2015; Sá Antunes et al. 2016).

Initially regarded as a PMeV subgenomic RNA, the $4.5 \mathrm{~kb}$ RNA band is now recognized as a genomic RNA from a second virus, $\mathrm{PMeV} 2$, associated with PMeV in infected plants from Brazil. Sequence alignment showed a high similarity between PMeV2 and umbraviruses (Sá Antunes et al. 2016). Umbraviruses are singlestranded RNA (ssRNA) viruses that do not encode a CP gene and, consequently, do not form conventional virus particles. Genome encapsidation and transmission requires an auxiliary virus, typically a polerovirus or an enamovirus. The hybrid virus particles, formed of the umbraviral RNA and the helper virus $\mathrm{CP}$, are transmitted by the helper virus vector (Taliansky and Robinson 2003).

Sá Antunes et al. (2016) showed, using degenerate primers targeting conserved domains of the $\mathrm{CP}$ gene from members of the Luteoviridae family, that there are no recognized poleroviruses, enamoviruses, or luteoviruses in symptomatic papaya plants. Peptides obtained by mass spectrometry from viral particles containing PMeV2 RNA match with the predicted amino acid sequence of PMeV ORF1. This indicates that hybrid virus particles are formed from $\mathrm{PMeV} \mathrm{CP}$ and $\mathrm{PMeV} 2$ ssRNA, supporting the idea that PMeV is an auxiliary virus for PMeV2 (Sá Antunes et al. 2016).

To the best of our knowledge, this is the first known case of an umbra-like virus associated with a totivirus and an early example in plants of a viral CP encapsidating viral ssRNA and dsRNA genomes (Fig. 2B). A similar relationship was shown by Zhang et al. (2016) in which the capsidless ssRNA mycovirus, yado-kari virus 1 (YkV1), using the CP of the dsRNA mycovirus yado-nushi virus 1 , forms hybrid particles encasing the YkV1 RdRp, allowing replication as a dsRNA virus.

$\mathrm{PMeV}$, but not $\mathrm{PMeV} 2$, can be detected in asymptomatic papaya plants, suggesting that this virus alone cannot induce PSD symptoms (Sá Antunes et al. 2016). This is similar to persistent viruses, which induce little or no overt effects on their hosts and do not encode a movement protein (Roossinck 2013). Although PMeV systemically infects papaya plants, no $\mathrm{PMeV}$ movement protein was reported

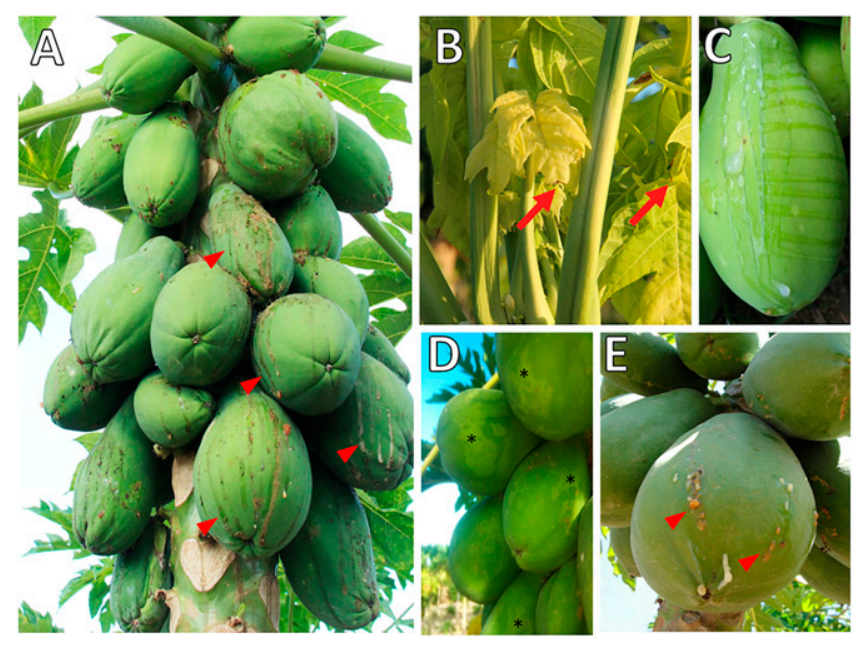

Fig. 1. Papaya sticky disease (PSD) symptoms. A, Papaya tree with green fruits presenting an exudation of fluid latex on their surface, which darkens after oxidation by atmospheric exposure resulting in a sticky aspect (red arrowhead). B, This exudation also results in the appearance of small necrotic lesions on the edges of young leaves (red arrow). C, Watery, fluid, and translucent latex of an infected fruit after wound with a scalpel. D, Irregular light-green and yellowish areas in green fruit (black asterisks). E, Papaya fruit from symptomatic Mexican plant (cv. Maradol).

Table 1. Viruses of papaya, by family and genus, in main growing regions worldwide

\begin{tabular}{|c|c|c|}
\hline Family & Genus & Virus species \\
\hline \multirow[t]{2}{*}{ Bunyaviridae } & Tospovirus & Tomato spotted wilt virus, TSWV \\
\hline & Tenuivirus & Papaya mild yellow leaf virus, PMYLV \\
\hline \multirow[t]{5}{*}{ Geminiviridae } & Begomovirus & Papaya leaf curl virus, PaLCuV \\
\hline & & Papaya leaf crumple virus, $\mathrm{PaLCrV}$ \\
\hline & & Chilli leaf curl virus, ChiLCuV \\
\hline & & Tomato leaf curl New Delhi virus, ToLCuNDV \\
\hline & & Croton yellow vein mosaic virus, CYVMV \\
\hline \multirow[t]{3}{*}{ Potyviridae } & Potyvirus & Papaya ringspot virus, PRSV-P \\
\hline & & Papaya leaf distortion mosaic virus, PLDMV \\
\hline & & Zucchini yellow mosaic virus, ZYMV \\
\hline \multirow[t]{2}{*}{ Rhabdoviridae } & Rhabdovirus & Papaya apical necrosis virus, PANV \\
\hline & & Papaya droopy necrosis virus, PDNV \\
\hline Tombusviridae ${ }^{\mathrm{a}}$ & Carmovirus $^{\mathrm{a}}$ & Papaya lethal yellowing virus, PLYV \\
\hline Alphaflexiviridae & Potexvirus & Papaya mosaic virus, PapMV \\
\hline $\mathrm{NE}^{\mathrm{b}}$ & $\mathrm{NE}^{\mathrm{b}}$ & Papaya meleira virus $^{\mathrm{b}}\left(\mathrm{PMeV}^{\mathrm{c}}+\mathrm{PMeV}-2^{\mathrm{d}}\right)$ \\
\hline
\end{tabular}

${ }^{a}$ Molecular research indicates homology with the family Sobemoviridae and genus Sobemovirus.

${ }^{\mathrm{b}}$ Not established. Molecular characterization of virus genome is in progress.

${ }^{\mathrm{c}}$ Tentatively classified in Totivirus genus.

${ }^{\mathrm{d}}$ Tentatively classified in Umbravirus genus. 
(E. F. M. Abreu et al. 2015; Sá Antunes et al. 2016). PMeV localization in laticifers and the increased latex exudation and fluidity during PSD (Kitajima et al. 1993) could be used by the virus to move systemically throughout the plant. Another possibility is that PMeV replicates in meristematic cells, allowing it to infect all plant tissues.
PMeV2 does not infect papaya on its own and all papaya plants displaying typical PSD symptoms have a double infection by PMeV and PMeV2. The apparent requirement of both PMeV and PMeV2 for PSD symptoms led to a reconsideration of the disease etiology in Brazil (Sá Antunes et al. 2016).

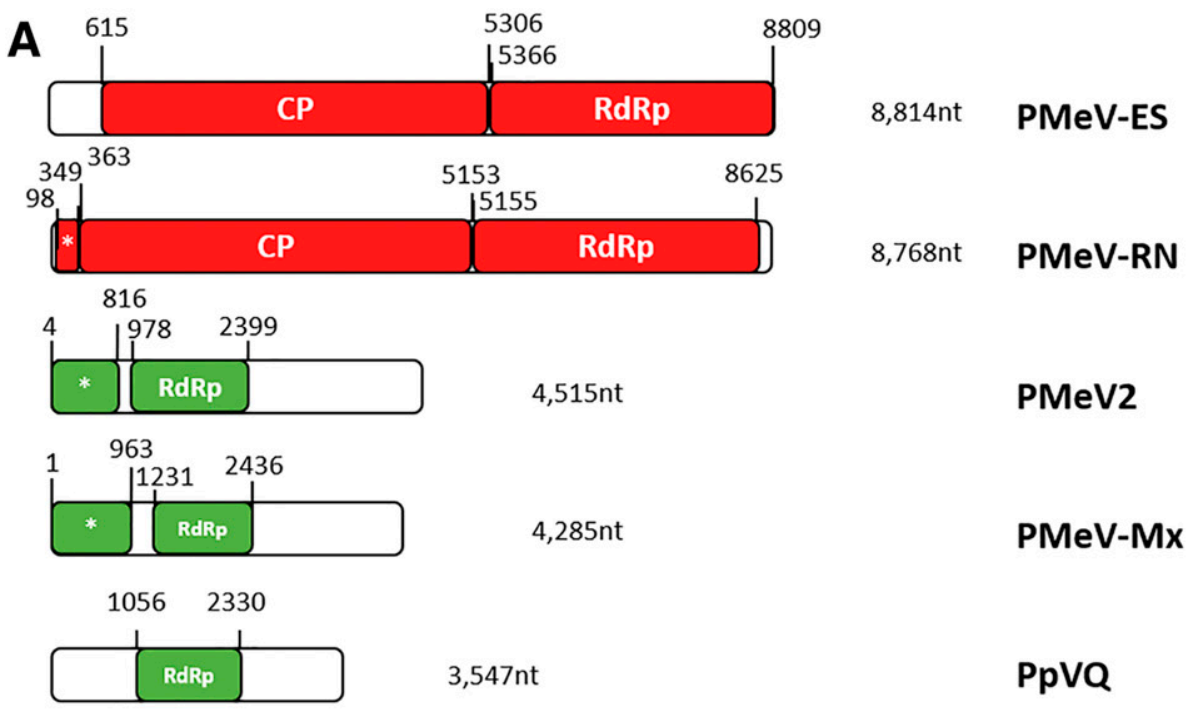

B
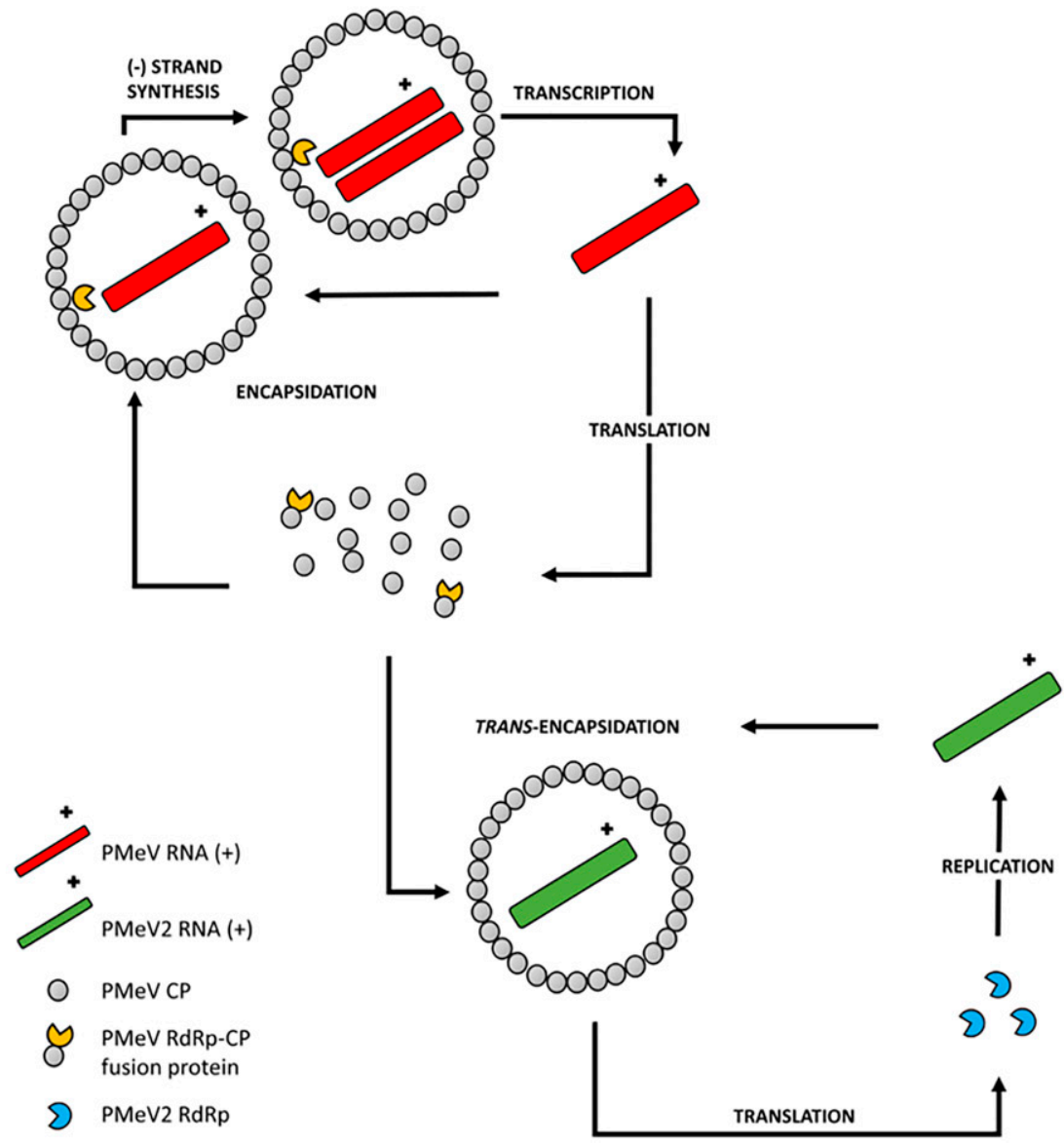

Fig. 2. Current isolates of PMeV and PMeV2 and proposed model for interactions between PMeV complex. A, Genomic organization of PMeV (red) and PMeV2 (green) isolates showing their ORFs and their putative encoded proteins. NCBI accession numbers: PMeV-ES (KT921784); PMeV-RN (KT013296); PMeV2 (KT921785); PMeV-Mx (KF214786.1); and PpVQ (KP165407). Hypothetical proteins are indicated with an asterisk. B, Papaya sticky disease (PSD) in Brazil occurs during a double infection by PMeV, a toti-like virus, and $\mathrm{PMeV} 2$, an umbra-like virus. A possible scenario for PMeV and PMeV2 interplay is illustrated here. PMeV can complete its replication cycle in the host cell without PMeV2. Like an umbravirus, $\mathrm{PMeV} 2$ is a capsidless ssRNA virus and is not found alone and uses PMeV CP for encapsidation. A -1 ribosomal frameshifting produces the RdRp-CP fusion protein 
In Mexico, similar symptoms to those of PSD were observed in papaya cv. Maradol. Gel electrophoresis of total RNA extracted from fruit latex also displayed two bands at approximately 10 and $4.5 \mathrm{~kb}$. The disease could also be transmitted through the latex of infected papaya to healthy papaya plants (Perez-Brito et al. 2012). Together, these findings indicated the same viral etiology for the Brazilian and Mexican diseases.

A cDNA library obtained from symptomatic plants identified an 1,154 bp sequence, partially covering the genome of the Mexican isolate (PMeV-Mx), showing high similarity to an umbravirus found in Ecuador (papaya virus Q - PpVQ) (Quito-Avila et al. 2015) and $\mathrm{PMeV} 2$, but no similarity to PMeV. Only one ORF with the characteristic domains of an RdRp has been predicted for PpVQ, while both $\mathrm{PMeV} 2$ and $\mathrm{PMeV}-\mathrm{Mx}$ have a putative uncharacterized ORF upstream to their RdRp (Fig. 2B). In addition, primers based on the Mexican isolate sequence amplified fragments from both Brazilian and Mexican symptomatic plants, and the amplicons had 100\% nucleotide identity (Zamudio-Moreno et al. 2015).

In 2019, PSD was officially reported for the first time in Queensland, Australia (Pathania et al. 2019). Although virus particles were observed in Australian plants with PSD symptoms, next-generation sequencing revealed only an umbra-like virus (PMeV2-Au) (Campbell 2018). Currently, the auxiliary virus for the Mexican and Australian isolates is unknown.

\section{Papaya and PMeV Complex Interaction}

During the interaction between viruses and plants, the virus hijacks host factors to complete its infecting cycle and the plant responds with a complex multilayered immune defense. In PSD, the outcome of this interaction depends on the papaya's development stage. Papaya is susceptible to the PMeV complex, but infected plants remain asymptomatic for 6 to 8 months (Ventura et al. 2004). This phenomenon supports the idea that a tolerance mechanism in preflowering plants allows the coexistence of plant and virus without causing significant loss of vigor or fitness to their hosts (Madroñero et al. 2018). For this reason, several physiological, biochemical, structural, and molecular aspects have been investigated to elucidate the interaction between the PMeV complex and pre- and postflowering papaya. We present a schematic view of this interaction in Figure 3.
PMeV complex effect on the laticifers. Alteration in the physical and chemical properties, and spontaneous exudation of papaya latex during PSD, suggested that the PMeV complex viruses could be directly involved in PSD symptoms (Rodrigues et al. 2009). Papaya proteases are usually activated during latex exudation and contribute to latex viscosity, the clotting process, and antiviral defense (Rodrigues et al. 2009). In PSD-affected plants, the reduction of protease levels and activity seems to have an inhibitory effect on latex coagulation, thus increasing its fluidity, which could facilitate its flow through laticifers and allow virus spread within the plant (Rodrigues et al. 2012). Additionally, the accumulation of $\mathrm{H}_{2} \mathrm{O}_{2}$, a systemic response elicitor (Rodrigues et al. 2009), could play a negative regulatory role in cysteine-protease activity, possibly by oxidizing and inactivating the active site of the enzyme. The negative modulation of papaya latex cysteine proteases could also be a viral strategy to delay the progression of programmed cell death (PCD) in laticifers (Solomon et al. 1999) and minimize virus particle degradation.

PMeV complex effect on the proteasome. The PMeV complex also has a role in other papaya tissues, including necrotic lesions on the leaf tip (Ventura et al. 2004). The global protein expression profile of PSD leaf tissues showed an accumulation of calreticulin, proteasome-related proteins such as $20 \mathrm{~S}$ proteasome b subunit, and stress-response proteins such as pathogenesis-related (PR) proteins, endochitinase, and PR-4, while proteins related to metabolism are downregulated (Rodrigues et al. 2012), demonstrating a major investment in plant defense (El Moussaoui et al. 2001).

The involvement of the ubiquitin/26S proteasome system (UPS) in the signaling and regulation of plant-pathogen interactions has been described in several studies (Sorel et al. 2019). The UPS machinery contributes to antiviral immunity by degrading viral effectors, but viruses can usurp the UPS machinery to target proteins that inhibit viral infection to the degradation pathway (Verchot 2016). The accumulation of proteasome-related proteins in PSD symptomatic papaya plants supports the idea that defense host proteins, which are essential for the plant response against viral infection, are targeted for degradation (Rodrigues et al. 2011).

During PMeV complex infection, the levels of several microRNAs (miRNAs) involved in the modulation of genes related to the UPS system are reduced. This indicates that PMeV co-opts the UPS

LEAF TISSUE
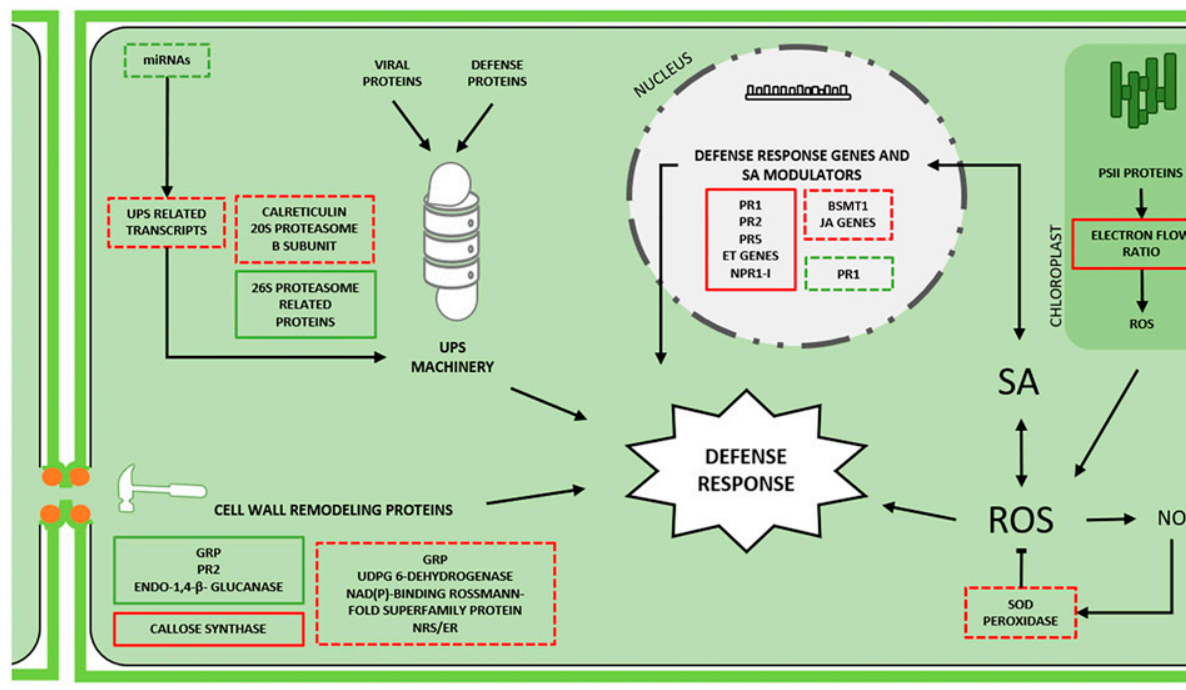

Fig. 3. Papaya and PMeV complex interaction. In preflowering plants, a multilayer immune system triggered by PMeV complex infection results in a preflowering tolerance that is partially disabled in postflowering. See the text (Papaya and PMeV complex interaction) for details and further references. SA, salicylic acid; $P R 1$, $P R 2$, and PR5 are pathogenesisrelated protein genes; BSMT1, benzoic acid/SA carboxyl methyltransferase; NPR1-I, nonexpressor of pathogenesis-related protein 1; ET, ethylene; JA, jasmonate; GRP, glycinerich protein; NRS/ER, nucleotide-rhamnose synthase/epimerase-reductase; UPS, ubiquitin/26S proteasome system; PCD, programmed cell death. ROS, reactive oxygen species; NO, nitric oxide; SOD, superoxide dismutase; PSII, photosystem II. Dashed box: postflowering events (PSD); solid box: preflowering events; red: induced or partially induced processes; green: repressed or partially repressed; black arrows: direction or order of the cellular event; blocked arrow: inhibition of the cellular event. Viral icosahedral particles and vesicles are represented in laticifer cells. 
system for its benefit, promoting virus replication, movement, and a rapid turnover of viral proteins. For example, structural proteins, generally produced in large amount in a short time, are not able to fold correctly, leading to the formation of misfolded proteins that are targeted for degradation (Alcaide-Loridan and Jupin 2012). Thus, we suggest that the rapid turnover of viral proteins can favor viral infection since it maintains an ideal cellular environment for plant and virus coexistence (Abreu et al. 2014; Verchot 2016).

In another study, the global protein profile of field-grown PMeVinfected preflowering C. papaya plants exhibited low levels of $26 \mathrm{~S}$ proteasome-related proteins (Soares et al. 2017), an opposite pattern to that previously observed for symptomatic plants (Rodrigues et al. 2011). Lower activity of the $20 \mathrm{~S}$ and $19 \mathrm{~S}$ proteasome increases the levels of polyubiquitinated proteins and increased PCD, which could successfully contain a virus infection (Rodrigues et al. 2011). However, the full spectrum of antiviral defenses involves the activity of caspase-like serine proteases (Citovsky et al. 2009; Rodrigues et al. 2011) such as subtilase 1.3, whose levels are reduced in PMeV-infected preflowering $C$. papaya tissues.

PMeV complex effect on redox balance and defense gene expression. Photosynthesis light-dependent reactions are important in plant responses against viruses and disturbances in this process favor viral accumulation (Soares et al. 2017). A higher electron flow ratio induced by the accumulation of photosynthesisrelated proteins in preflowering infected papaya (Soares et al. 2017) promotes a cascade of events in chloroplasts leading to reactive oxygen species (ROS) production. Low ROS levels induce antioxidant enzymes; however, when the ROS levels reach a certain threshold, a signal transduction pathway is activated that eventually leads to PCD (Solomon et al. 1999). ROS-related metabolic changes occur in C. papaya-PMeV complex interactions, including an increase in $\mathrm{H}_{2} \mathrm{O}_{2}$ production in the laticifers (Rodrigues et al. 2009). Moreover, preflowering $C$. papaya leaves treated with nitric oxide (NO) show an accumulation of compounds used for defense and an increased activity of detoxification enzymes (Buss et al. 2011). Supporting these data, several genes coding for ROS-detoxifying enzymes in PMeV complex-infected plants are upregulated at preflowering (Madroñero et al. 2018). Although defense mechanisms such as ROS-signaling features are present at an early stage of infection, this is not enough to mediate resistance.

ROS has signaling effects in the chloroplast itself and other parts of the cell, often involving hormonal crosstalk that regulates the activation of defenses in plants, especially salicylic acid (SA) (Xia et al. 2015). At preflowering, $P R 1, P R 2, P R 5$, and other genes involved in SA-signaling are upregulated. Moreover, the exogenous application of SA on preflowering plants before virus inoculation results in a trend of diminished viral load (Madroñero et al. 2018). These insights indicate the existence of defense mechanisms at preflowering, which could hamper the development of PSD symptoms. However, other genes known for their antagonistic roles in SA signaling, such as genes involved in ethylene metabolism and the NPR1-inhibitor, are also upregulated, which could prevent full-scale and enduring resistance. At postflowering, the PRl gene is downregulated and negative modulators of SA signaling are upregulated (Madroñero et al. 2018). Together, the development of symptoms during postflowering implies an incomplete activation of defense response mechanisms upon $\mathrm{PMeV}$ complex infection.

PMeV complex effect on cell wall structure. The PMeV complex spread could also be facilitated by changes in structure and composition of the papaya cell wall during the switch to the flowering stage. At preflowering, infected plants show modulation of transcripts coding for cell wall remodeling and structural proteins that may be part of the papaya response to hamper PMeV complex traffic (Madroñero et al. 2018; Soares et al. 2017). At postflowering, in contrast, cell wall genes are induced in infected plants, which indicates that the PMeV complex could be inducing cell wall turnover at the plasmodesmata site to promote systemic viral infection. Analysis of the topography and mechanical properties of PSD leaves show that their midribs are fragile and susceptible to breakage (MagañaÁlvarez et al. 2016), which suggests a weakening in the cell walls of leaf tissues that could extend to laticifers. Cell rupture and latex exudation, the main symptoms in PSD plants, could be explained by cell wall turnover associated with increased water content and internal pressure.

\section{Epidemiology}

The epidemiological behavior of PSD has been extensively studied (E. F. M. Abreu et al. 2015; Rodrigues et al. 1989; Tapia-Tussell et al. 2015; Ventura et al. 2003). Environmental factors and agricultural practices have been the main factors responsible for the disease progression and appearance of symptoms in the field, which may vary according to the source of virus inoculum (seed, alternative hosts, or vectors) and papaya variety.

Until 2012, most studies on PSD were based on the virus detection through the visualization of the viral dsRNA band on agarose gel electrophoresis. The sequencing of both PMeV and PMeV2 (Sá Antunes et al. 2016) allowed the development of more sensitive techniques such as RT-PCR (Abreu et al. 2012; Maurastoni et al. 2020; Sá Antunes et al. 2016) and qRT-PCR (Abreu et al. 2012), which have been applied to understand key aspects of the PSD epidemiology.

Observations of PSD dispersal patterns in orchards pointed to insects as PMeV complex vectors. In a study conducted in Brazil, after exposure to whiteflies (Bemisia tabaci type B) that fed on infected plants, asymptomatic papaya plants developed PSD symptoms and PMeV dsRNA was detected. However, the virus was not detected in these whiteflies, which are not a papaya pest (Vidal et al. 2003). Several whiteflies can transmit viruses in a nonpropagative manner in which viruses are not internalized inside the insect cells. Viral retention time in the insect's body depends on the virus half-life and viral load is often low (Whitfield et al. 2015). Therefore, the absence of PMeV dsRNA in B. tabaci type B does not exclude an ability to transmit the PMeV complex.

Another whitefly commonly found in papaya orchards and considered a pest to Brazilian papaya is Trialeurodes variabilis. This whitefly appears unable to transmit viral dsRNA from inoculated plants to healthy plants (Rodrigues et al. 2009). The dsRNA was detected in adults and nymphs but not in latex collected from plants 20 days after being exposed to the viruliferous whiteflies. However, the ability of $T$. variabilis to vectorize the $\mathrm{PMeV}$ complex cannot be ruled out as the time required for dsRNA visualization may be longer than that analyzed.

Recently, leafhoppers (Hemiptera: Cicadellidae) were proposed as a potential $\mathrm{PMeV}$ complex insect vector in Brazil as their distribution in the crop is correlated with the distribution of disease (Gouvea et al. 2018). In Mexico, Empoasca papayae Oman (Hemiptera: Cicadellidae) adults, but not nymphs, have been shown to transmit PMeV-Mx to C. papaya cv. Maradol. These leafhoppers can acquire the virus after $6 \mathrm{~h}$ exposure to infected plants and viral titer increases with longer exposure time (up to 5 days). Little is known about the biology of $E$. papayae and research is now focused on understanding the behavior of this insect in the field (García-Cámara et al. 2019). In Brazil, transmission experiments to study leafhoppers' ability to vectorize PMeV complex are necessary to implement adequate management strategies.

The identification of alternative hosts for the $\mathrm{PMeV}$ complex is also essential for the development of control strategies. In Brazil, several plants were tested for their susceptibility to $\mathrm{PMeV}$ infection, but the dsRNA was detected only in Brachiaria decumbens (Poaceae) (Maciel-Zambolim et al. 2003), which is commonly found close to papaya plantations. In Mexico, the intercropping between watermelons (Citrullus lanatus Thunb.) and papayas led to the hypothesis that watermelons could be an alternative host for PMeV$\mathrm{Mx}$. Indeed, PMeV-Mx can replicate in watermelon seedlings and, more surprisingly, induce necrotic lesions on the leaf tip, a typical PSD symptom (García-Cámara et al. 2018). The alternative hosts proposed by Maciel-Zambolim et al. (2003) need to be revisited using more sensitive techniques, with additional detection for PMeV2. $B$. decubems and C. lanatus Thunb. also need to be assessed as viral reservoirs. 
Understanding PSD etiology, dynamics of viral populations, and transmission are imperative for integrated management of papaya production. Since PSD symptoms appear only after flowering, an infected asymptomatic plant may remain an undetected virus source for months before being eradicated. Thus, an efficient strategy for virus control remains a challenge.

\section{Management of Papaya Virus Diseases}

The papaya crop has experienced significant improvements through the use of innovative technologies (Costa et al. 2019). However, there are significant challenges, necessitating quality and genetically certified seeds and cultivars, and most of all, resistance to major crop diseases (Ventura et al. 2019). Several strategies have been recommended for papaya virus control. The major control strategies applicable to all papaya viruses are the following:

1. Use of healthy seeds and exclusion of the pathogens by seedling/crop certification. PSD has been reported as a seed-borne disease in Mexico and Australia and the use of healthy seeds in new plantations has been recommended (Tapia-Tussell et al. 2015). The Australian government initiated a program to produce clean seeds (Campbell 2019b) using embryo rescue and tissue culture, which was able to produce 98\% PMeV2-free plants (Campbell 2019a).

A seed transmission route has not yet been confirmed for the $\mathrm{PMeV}$ complex in Brazil. However, measures have been adopted by Brazilian farmers to mitigate the possible dispersion of PSD and other viral diseases: (i) the use of certified seedlings in the establishment of new orchards; (ii) the use of seeds from plants that have been grown under conditions that will prevent infection; (iii) the establishment of nurseries and orchards as far as possible from other orchards especially if viral diseases had been reported in the region; (iv) exclusion of the pathogens by crop quarantine.

2. Control of pathogen by eradication (roguing) of infected plants. Viruses can spread both within and between orchards. Growers and field workers must learn to identify the early symptoms of viral diseases. The best way to manage the virus is the prompt identification and immediate destruction of diseased trees, as delays enable the virus to spread to additional trees (Ventura et al. 2003). Additionally, the possibility of virus spread from asymptomatic papaya implies a need for additional disease management strategies such as early detection of the PMeV complex (Maurastoni et al. 2020).
In Brazil, the roguing practice is governed by Normative Instruction number 17, May 27th, 2010. Weekly inspections are performed throughout the entire crop, and plants with PSD symptoms are removed (Fig. 4A) (Ventura et al. 2004). From 2011 to 2014, more than 4.9 million plants were eradicated in the largest papaya exporting state in Brazil, preventing the spread of various diseases to healthy orchards (Fig. 4) (Fernandes et al. 2018).

3. Control of pathogen vectors. Several papaya viral pathogens have insect vectors and their control plays an important role in the management of papaya diseases. The efficacy of insecticide is determined by the manner of transmission, vector population dynamics, and vector host range (Perring et al. 1999). In noncirculative transmitted viruses such as PRSV-P, the use of chemical treatments results only in the reduction of the populations of potential vectors and prevention of plant colonization, without preventing the transmission. While the insect that vectorizes PSD-associated viruses is still unknown in Brazil, Mexico, and Australia, measures used to control the PRSV-P vectors have also been adopted for PSD control. An insecticide control strategy can be enhanced by using additional control measures, such as the elimination of weeds before the major peak of aphid flights, which could prevent the vector from acquiring virus from reservoir plants, disrupting the virus cycling.

4. Selection of tolerant and/or resistant cultivars. The development of papaya resistance cultivars for virus control has been recognized as the most viable strategy. Since $C$. papaya cultivars are susceptible to several viruses, breeders have been seeking sources of resistance in other species within the family Caricaceae. Resistance to PRSV-P has been found in the genus Vasconcellea but its use in conventional breeding has been hampered by sexual incompatibility between species (Haireen and Drew 2014; Lin et al. 2019). No resistance to the $\mathrm{PMeV}$ complex has yet been found in 30 C. papaya genotypes or in noncultivated plants (Meissner Filho et al. 2017).

Expression of pathogen-derived genes interferes with the virus cycle in the host plants, inhibiting the viral infection. So far, PRSVresistant transgenic papaya have been developed based on a sequence homology-dependent strategy (Azad et al. 2014; Jia et al. 2017), which requires knowledge of the virus diversity for its success. Transgenic resistance to PRSV-P has already been broken due to the emergence of divergent virus strains (Jia et al. 2017). To date, two PMeV isolates have been identified in Brazil (E. F. M. Abreu
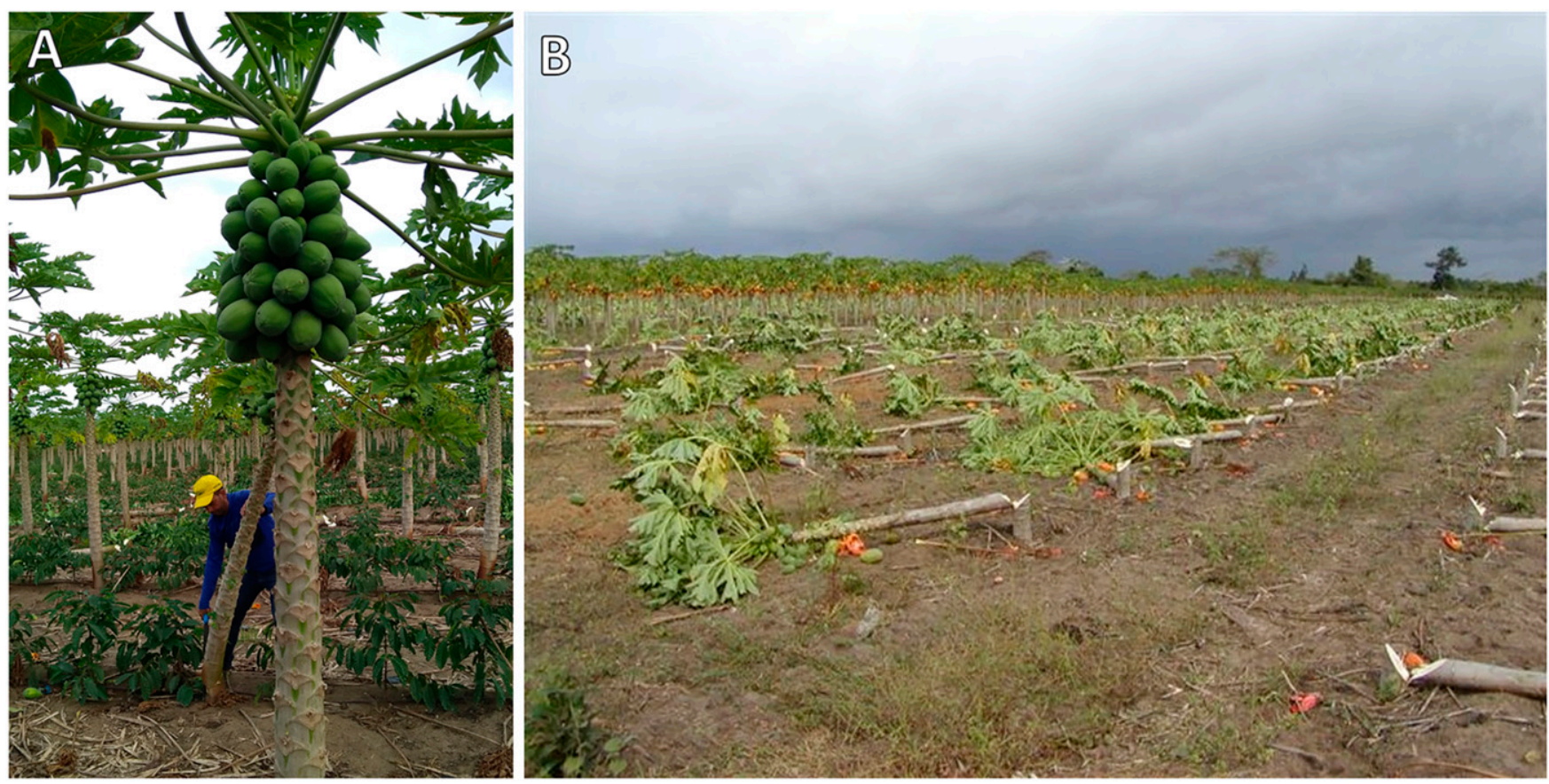

Fig. 4. The roguing of infected plants. A, An agricultural technician specialized in recognizing plants with papaya ringspot and papaya sticky disease (PSD) symptoms, known in Portuguese as 'mosaiqueiro,' performs the roguing using a machete. Until now, this is the only management applied to control PSD. B, If appropriate agricultural practices are not carried out, the disease spreads to the whole crop and brings about total yield loss. 
et al. 2015; Sá Antunes et al. 2016). Although their CPs share 75\% similarity, studies with more isolates are required to understand $\mathrm{PMeV}$ diversity so that unlike PRSV, the PMeV complex will not overcome transgenic resistance.

5. Control of alternative hosts. The possibility of papaya virus spread from alternative hosts necessitates management strategies for weed control (Alcalá-Briseño et al. 2020). Pathogen emergence results from interactions between susceptible hosts and pathogenic viruses in conducive environments, causing disease outbreaks in new geographic regions or hosts (Alcalá-Briseño et al. 2020). In addition to the removal of weeds that grow close to papaya plants, special attention should be given to plants that are confirmed as a reservoir for the PMeV complex in Brazil and Mexico.

6. Cleaning harvesting tools. Spatial distribution of the $\mathrm{PMeV}$ complex was studied in experimental plots over a year, and a high percentage of infected plants $(\sim 78 \%)$ per line during and after the harvest pointed to mechanical transmission (P. M. V. Abreu et al. 2015; Ventura et al. 2003). This implies that agricultural practices, including fruit thinning, are also responsible for the spread of PSD within orchards.

In orchards where appropriate agricultural practices were not carried out, the disease spread to the whole crop and led to total yield loss. In contrast, in orchards that strictly followed these principles including a weekly plant eradication based on the presence of initial PSD symptoms, the incidence of eradicated plants was less than 5\% during the crop cycle (Ventura et al. 2004, 2019).

\section{Closing Remarks and Future Prospects}

Over the last decade, a lot has been learned about PSD including the etiology, epidemiology, defense mechanism of papaya against $\mathrm{PMeV}$ complex, and disease management strategies. In the 1990s, the causal agent of PSD was identified as a dsRNA virus, PMeV, but in 2016 a second virus, PMeV2, with an ssRNA genome, was also discovered in PSD plants. All PSD symptomatic papaya plants are infected by the two viruses; however, asymptomatic plants analyzed in Brazil were positive only for PMeV. Thus, evidence suggests that contrary to what was originally believed, PMeV is not the etiological agent of PSD. Interestingly, in countries other than Brazil where PSD has been reported, only the umbra-like virus has been identified. Thus, it is possible that a different helper virus may be identified in these countries.

An intriguing question has been why infected plants remain without symptoms until flowering. Proteomic and transcriptomic data have increased our understanding of the interaction between papaya and the PMeV complex. The infected papaya plant mounts an antiviral defense mechanism during preflowering, when several genes related to the SA pathway and other defense pathways are highly expressed. However, increased expression of genes at postflowering that negatively regulate SA production leads to depression in defense responses.

Plant virus diseases cause serious reductions to crop production and quality worldwide. The susceptibility of papaya plants to viruses leads to an economic and environmental impact as it increases the use of agrochemical products and water resources, without achieving the predicted crop yield. PSD may affect $20 \%$ of the plants during the economic cycle of the crop in orchards where roguing is performed, but it affects up to $100 \%$ of the plants where phytosanitary protocols are not implemented, causing a total yield loss (E. F. M. Abreu et al. 2015).

The development of papaya plants resistant to viruses is urgently needed. Plants challenged by viral RNA initiate defense responses based upon RNA silencing, and this strategy was used to develop virus-resistant crops (Lindbo and Falk 2017). Resistance to infection against a range of individual viruses has been engineered into several plant species. Because of the durability and success of transgenic papaya cultivars in Hawaii, U.S.A., similar transgenic papaya plants have been engineered in other countries. Resistance, however, was inconsistent for many reasons, such as the emergence of recombinant strains, increased strength of viral silencing suppressors, and unfavorable environmental conditions.

Brazilian researchers have been working on the development of resistant papaya to combat PSD. Until 2016, PSD was associated only with $\mathrm{PMeV}$, and all efforts to obtain a resistant plant considered only this virus. Now, groups working toward this goal must consider both viruses, as well as the defense mechanisms activated in papaya-PMeV/PMeV2 interactions reviewed in the present paper, if a breeding program to develop a PSD-resistant papaya plant is to realistically succeed.

\section{Literature Cited}

Abreu, E. F. M., Daltro, C. B., Nogueira, E. O. P. L., Andrade, E. C., and Aragão, F. J. L. 2015. Sequence and genome organization of papaya meleira virus infecting papaya in Brazil. Arch. Virol. 160:3143-3147.

Abreu, P. M. V., Antunes, T. F. S., Magaña-Álvarez, A., Pérez-Brito, D., TapiaTussell, R., Ventura, J. A., Fernandes, A. A. R., and Fernandes, P. M. B. 2015 A current overview of the Papaya meleira virus, an unusual plant virus. Viruses 7:1853-1870.

Abreu, P. M. V., Gaspar, C. G., Buss, D. S., Ventura, J. A., Ferreira, P. C. G., and Fernandes, P. M. B. 2014. Carica papaya microRNAs are responsive to Papaya meleira virus infection. PLoS One 9:e103401.

Abreu, P. M. V., Piccin, J. G., Rodrigues, S. P., Buss, D. S., Ventura, J. A., and Fernandes, P. M. B. 2012. Molecular diagnosis of Papaya meleira virus (PMeV) from leaf samples of Carica papaya L. using conventional and real-time RTPCR. J. Virol. Methods 180:11-17.

Alcaide-Loridan, C., and Jupin, I. 2012. Ubiquitin and plant viruses, let's play together! Plant Physiol. 160:72-82.

Alcalá-Briseño, R. I., Casarrubias-Castillo, K., López-Ley, D., Garrett, K. A., and Silva-Rosales, L. 2020. Network analysis of the papaya orchard virome from two agroecological regions of Chiapas, Mexico. mSystems 5:e00423-19.

Azad, M. A. K., Amin, L., and Sidik, N. M. 2014. Gene technology for papaya ringspot virus disease management. Sci. World J. 2014:768038.

Buss, D. S., Dias, G. B., Santos, M. P., Ventura, J. A., and Fernandes, P. M. B. 2011. Oxidative stress defence response of Carica papaya challenged by nitric oxide, Papaya meleira virus and Saccharomyces cerevisiae. Open Nitric Oxide J. 3:55-64.

Campbell, P. 2018. New test to offer early detection of papaya sticky disease. Papaya Press. https://australianpapaya.com.au/website/wp-content/uploads/ 2018/05/PAPAYAPRESS-MAY.pdf

Campbell, P. 2019a. Papaya clean seed update. Papaya Press. https:// australianpapaya.com.au/website/wp-content/uploads/2019/11/CIC_106337_ PAPAYAPRESS_NOV-2019 WEBREADY.pdf

Campbell, P. 2019b. Papaya clean seed program underway. Papaya Press. https:// australianpapaya.com.au/website/wp-content/uploads/2019/05/CIC_106081_ PAPAYAPRESS_MAY-201905-WEBREADY.pdf

Chávez-Calvillo, G., Contreras-Paredes, C. A., Mora-Macias, J., Noa-Carrazana, J. C., Serrano-Rubio, A. A., Dinkova, T. D., Carrillo-Tripp, M., and SilvaRosales, L. 2016. Antagonism or synergism between papaya ringspot virus and papaya mosaic virus in Carica papaya is determined by their order of infection. Virology 489:179-191.

Citovsky, V., Zaltsman, A., Kozlovsky, S. V., Gafni, Y., and Krichevsky, A. 2009 Proteasomal degradation in plant-pathogen interactions. Semin. Cell Dev. Biol. 20:1048-1054.

Costa, A. F. S. d., Abreu, E. F. M., Schmildt, E. R., Costa, A. N. d., and Schmildt, O. 2019. Advances observed in papaya tree propagation. Rev. Bras. Frutic. 41:e-036.

El Moussaoui, A., Nijs, M., Paul, C., Wintjens, R., Vincentelli, J., Azarkan, M., and Looze, Y. 2001. Revisiting the enzymes stored in the laticifers of Carica papaya in the context of their possible participation in the plant defence mechanism. Cell. Mol. Life Sci. 58:556-570.

FAO. 2017. Food outlook - Biannual report on global food markets. FAO, Rome. http://www.fao.org/3/a-I8080e.pdf

FAO. 2019. Food outlook - Biannual report on global food markets. FAO, Rome http://www.fao.org/3/ca6911en/CA6911EN.pdf

FAOSTAT. 2018. Food and Agriculture Organization of the United Nations. FAO, Rome. http://www.fao.org/faostat/en

Fauquet, C., and Fargette, D. 2005. International Committee on Taxonomy of Viruses and the 3,142 unassigned species. Virol. J. 2:64.

Fernandes, P. M. B., Fernandes, A. A. R., Ventura, J. A., Antunes, T. F. S. Quadros, O. F., Madroñero, J., Carminati, L. S., and Maurastoni, M. 2018. Um novo complexo viral: o caso da meleira do mamoeiro. VII Simpósio do Papaya Brasileiro. Produção e Sustentabilidade, Vitória, Espírito Santo, Brazil.

García-Cámara, I., Pérez-Brito, D., Moreno-Valenzuela, O., Magaña-Álvarez, A., Fernandes, P. M. B., and Tapia-Tussell, R. 2018. Molecular and experimental evidence of Watermelon (Citrullus lanatus) as host of the Mexican variant of Papaya meleira virus. Eur. J. Plant Pathol. 151:117-123.

García-Cámara, I., Tapia-Tussell, R., Magaña-Álvarez, A., Cortés Velázquez, A., Martín-Mex, R., Moreno-Valenzuela, O., and Pérez-Brito, D. 2019. Empoasca papayae (Hemiptera: Cicadellidae)-mediated transmission of Papaya meleira virus-Mexican variant in Mexico. Plant Dis. 103: 2015-2023.

García-Viera, M., Sánchez-Segura, L., Chavez-Calvillo, G., Jarquín-Rosales, D., and Silva-Rosales, L. 2018. Changes in leaf tissue of Carica papaya during 
single and mixed infections with Papaya ringspot virus and Papaya mosaic virus. Biol. Plant. 62:173-180.

Gouvea, R., da Vitória, R., Rosa, R., Alves, W. S., Giuriatto, N., Calatroni, D., Fanton, C., Martins, D. S., and Queiroz, R. 2018. Flutuação populacional de cigarrinhas (Hemiptera: cicadellidae) e ocorrência do vírus da meleira do mamoeiro. VII Simpósio do Papaya Brasileiro. Produção e Sustentabilidade, Vitória-Espírito Santo, Brazil.

Haireen, M. R. R., and Drew, R. A. 2014. Isolation and Characterisation of PRSV-P Resistance Genes in Carica and Vasconcellea. Int. J. Genomics 2014:145403.
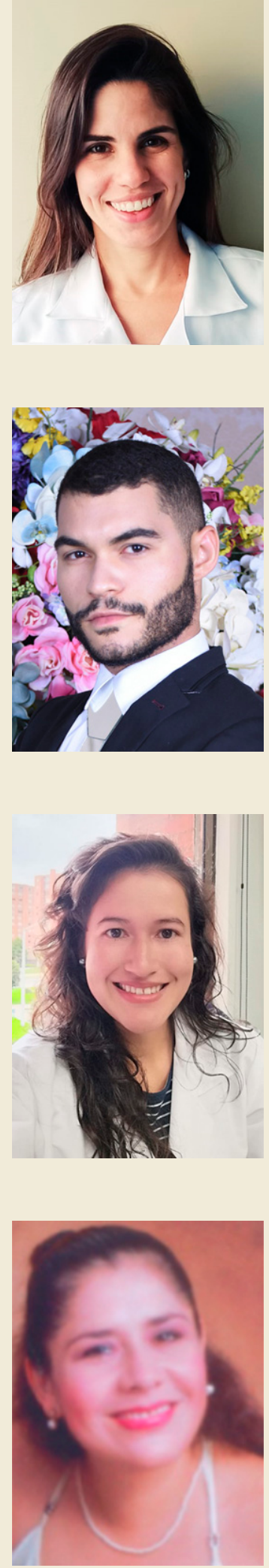

Dr. Tathiana Sá Antunes holds a postdoctoral position at the laboratory of biotechnology applied for agribusiness in the Federal University of Espirito Santo. Tathiana received her B.Sc. in biochemistry from the Federal University of Viçosa (2009) and a Ph.D. in biotechnology from the Federal University of Espirito Santo (2017). One of Tathiana's significant contributions to her research field was the discovery of a second virus, papaya meleira virus 2, associated with papaya sticky disease in Brazil. This finding brought out a new disease etiology and a more accurate diagnostic method. She was a visiting scholar at Centro de Investigación Científica de Yucatán when she researched the viruses associated with papaya sticky disease in Mexico. Her research focus is on virus-host interaction, diagnostic tools for virus detection in plants, and the identification and characterization of new virus-caused plant diseases. Her ongoing projects include the understanding of molecular mechanisms involved in papaya response against papaya meleira virus complex and the development of a papaya resistant cultivar.

Marlonni Maurastoni has focused his studies on plant-microbe interactions, on both cellular and molecular levels. He has a particular interest in the papaya meleira virus capsid protein and how the interaction with proteins present on laticifers could help in virion assembly. He is a Ph.D. student at the Federal University of Espirito Santo, Brazil. He got his bachelor's degree in biological sciences in 2016 and his master's degree in plant biology in 2018 when he developed three patents on the production of virus-free propagative material and molecular diagnosis. He started his Ph.D. in 2018 and spent time as a visiting scholar at Federal University of Viçosa - Brazil, Brazilian Agricultural Research Corporation (EMBRAPA) Genetic Resources and Biotechnology (CENARGEN) - Brazil, and North Carolina State University, U.S.A. His study has been centered on toti-like viruses that infect plants, mainly their capsid protein structures and functions, and the development of molecular diagnostic tools. He thus works at the intersection between agronomy and plant pathology using molecular biotechnological approaches to solve problems related to emerging plant diseases.

Johana Madroñero obtained her B.Sc. in biology from Universidad Nacional de Colombia in 2012. She received her M.Sc. in 2014 and her Ph.D. in biotechnology in 2018 from Universidade Federal do Espírito Santo in Brazil. She has a wide experience in molecular biology (9 years) and bioinformatics (6 years) by working with data from different "omics" technologies, such as genomics, transcriptomics, proteomics, and metagenomics. Currently, she is a professor and researcher at the Universidad el Bosque and Universidad Nacional Abierta y a Distancia (UNAD) in Bogotá, Colombia. At these universities, her academic and professional background is focused on accomplishing three main objectives: 1) Generation of knowledge of high academic impact through investigation and extension in areas related to microbiology, biochemistry, and biotechnology; 2) transfer of knowledge through education; and 3) formulation and management of projects aimed at the application of biotechnology and data analyses in health, industry, and agribusiness.

Dra. Gabriela Fuentes obtained her Ph.D. in biological sciences and plant biotechnology at the Scientific Research Center of Yucatan - CICY, Mexico. She did her postdoctoral research at the University of Laval, Quebec, Canada; at the Center for Research and Advanced Studies of the National Polytechnic Institute (CINVESTAV - Mérida Unit); at the Resources of the Sea Department; at CICY; and at the Germplasm Bank, Sierra Papacal Unit, Yucatan, Mexico. She has published 21 international articles and 9 book chapters. She has participated in 10 research projects with national and international financing. She has participated in 16 national and 24 international congresses. Her line of work is genomics, transcriptomics, and phenomics of abiotic stress (high temperature, drought, etc.) due to climate change in tropical species, as well as clean technologies in water bodies using plants. 
Jia, R., Zhao, H., Huang, J., Kong, H., Zhang, Y., Guo, J., Huang, Q., Guo, Y., Wei, Q., Zuo, J., Zhu, Y. J., Peng, M., and Guo, A. 2017. Use of RNAi technology to develop a PRSV-resistant transgenic papaya. Sci. Rep. 7:12636. Kitajima, E. W., Rodrigues, C. H., Silveira, J. S., Alves, F., Ventura, J. A., Aragao, F. J. L., and Oliveira, L. H. R. 1993. Association of isometric viruslike particles, restricted to lacticifers, with "meleira" (sticky disease) of papaya (Carica papaya). Fitopatol. Bras. 18:118-122

Lin, Q., Singh, R., and Yu, Q. 2019. Isolation and characterization of translation initiation factor 4E in Carica papaya and Vasconcellea species. Acta Hortic. 1250:39-44.
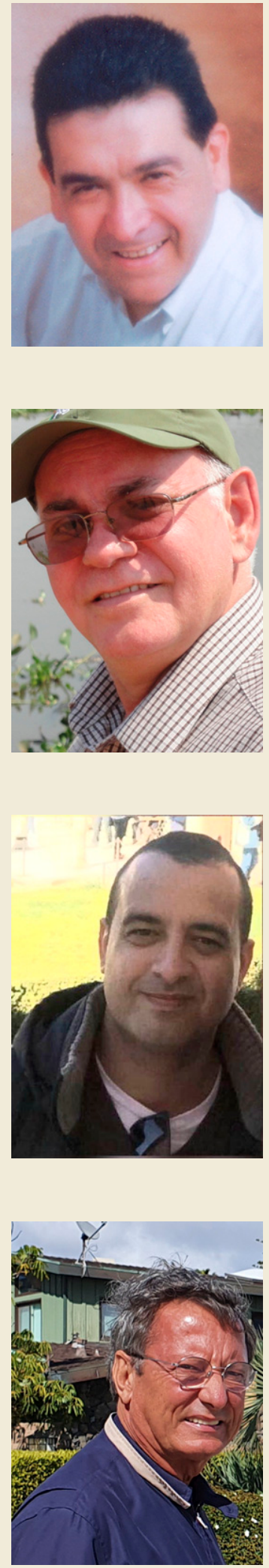

Dr. Jorge M. Santamaría Fernández is a senior researcher at the Biotechnology Department of the Scientific Research Center of Yucatan (CICY) and former research director at CICY, member of the Mexican Academy of Science, member of the Researchers National System, level III, and vice president of the Mexican Network of Plant Physiologists. He is chair of the ISHS Papaya Group. His research field is the physiological and molecular aspects of plant responses to biotic and abiotic stresses. He obtained his M.Sc. from The University of Queensland, Australia, and his Ph.D. from Lancaster University, UK. He has undertaken postdoctoral stays at ATO/DLO, Wageningen, The Netherlands, and ORSTOM and Université Paris-XI, Orsay, Paris, France, as well as a research stay as invited professor at INAF, Laval University, Quebec, Canada. He has more than 135 publications and has directed more than 60 theses, including $12 \mathrm{Ph} . \mathrm{D}$. theses. He is interested in the response of papaya plants to diseases such as viruses and anthracnose. He is currently involved in transcriptomic studies to understand the role of transcription factors in the response of papaya plants to climate change (heat and drought). He is also interested in understanding physiological and molecular aspects of plant responses to heavy metals.

Dr. José Aires Ventura is a senior research plant pathologist at Capixaba Institute of Research, Technical Assistance and Rural Extension (Incaper), and a professor of plant biotechnology in the Federal University of Espírito Santo (Ufes) at the Agribusiness Biotechnology Nucleus and Plant Biology, Brazil. He received his M.Sc. and Ph.D. degrees in plant pathology from the Department of Plant Pathology at Federal University of Viçosa, Brazil. His career was devoted principally to diseases of tropical fruit crops. In the last 40 years, his research has focused primarily on epidemiology, resistance, hostpathogen interaction, and disease management on papaya, pineapple, and bananas. He was techni$\mathrm{cal}$ director from 1995 to 1999 and head of research at Incaper from 2000 to 2016 . He was honored by Brazilian Phytopathological Society (SBF) in 1995 with the plant pathology award, and in 2006 with the Embrapa Frederico de Meneses Veiga national award for his relevant research on diseases of tropical fruits. He was also granted the research productivity award from the National Council for Scientific Technological Research (PQ). Dr. Ventura is a member of the Brazilian Phytopathological Society and The American Phytopathological Society (APS).

Dr. Emanuel Felipe Medeiros Abreu has vast experience in advanced biology applied to genetic improvement with focus on biotechnology for resistance to plant viruses. Laboratory activities include cloning of resistance and defense-related genes and his main publications are on papaya and passion fruit viruses. He graduated in biological sciences from the Federal University of Ceará (2004) and obtained his master's degree in botany (2006) and his Ph.D. in molecular biology (2012), both from the University of Brasilia. Dr. Abreu joined the Brazilian Agricultural Research Corporation (EMBRAPA) as a research analyst in 2008. He is a reviewer for the most current literature on molecular mechanisms of plant responses to pathogen invasion. Currently, he works at Embrapa Genetic Resources and Biotechnology, Brasília, Brazil, where he is the leader of the Biotechnology Applied to Biotic and Abiotic Stress in Plants Group.

Dr. A. Alberto R. Fernandes, full professor at the Federal University of Espírito Santo, Brazil, obtained his degree in physics from the Federal University of Rio de Janeiro (1978), his master's degree (1982) and Ph.D. (1988) in material sciences from the Military Institute of Engineering, Rio de Janeiro, and his post-doctorate at the University of California, San Diego (1990-92). He was the former general coordinator of micro and nanotechnology at the Ministry of Science and Technology of Brazil. In academic administration, he worked at the Military Institute of Engineering as graduate dean and a member of the Permanent Teaching Commission; at the Federal University of Espírito Santo as a member of the teaching and research council, president of the Teaching Policy Commission, director of the Department of Graduate Studies and Human Resources, and former director of the University Innovation Institute. Has acted as scientific consultant for several Brazilian financial agencies. He is a member of the State Deliberative Council of Brazilian Micro and Small Business Support Service. Has experience in the area of condensed matter physics, biotechnology, and innovation. He has published 59 scientific papers with 482 citations, with $\mathrm{H}$ factor equal to 13. 


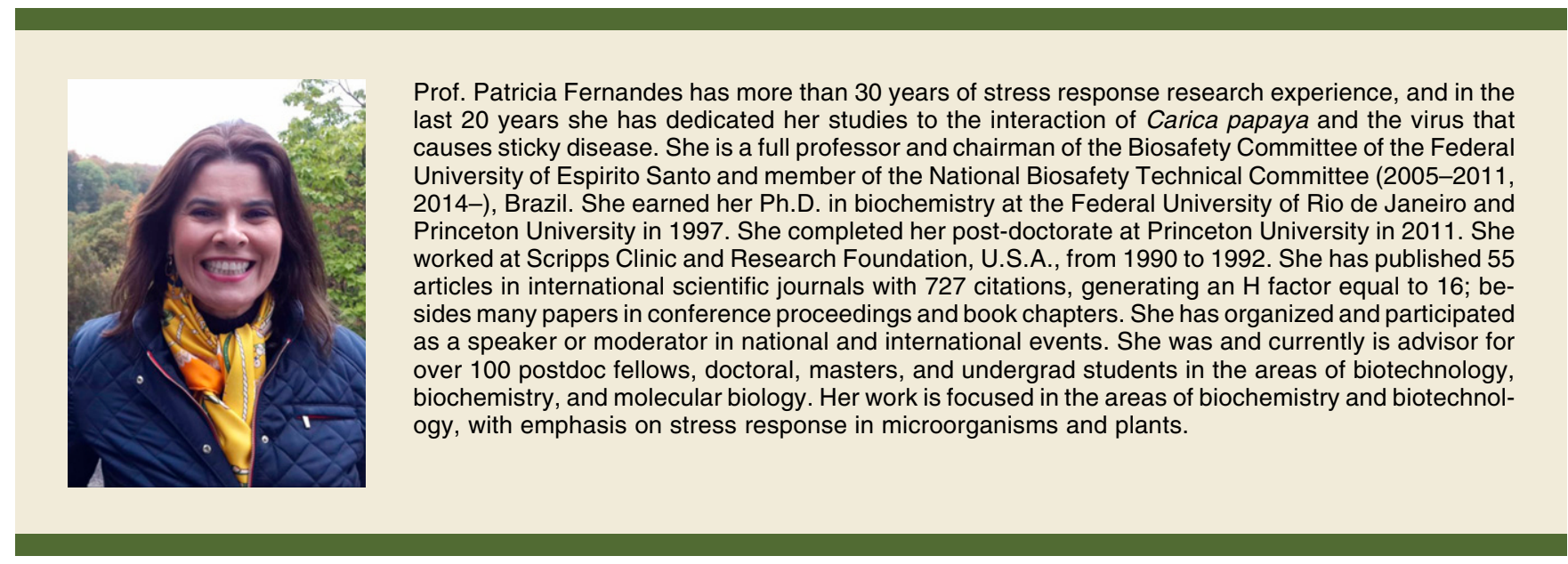

Lindbo, J. A., and Falk, B. W. 2017. The impact of "coat protein-mediated virus resistance" in applied plant pathology and basic research. Phytopathology 107: 624-634.

Maciel-Zambolim, E., Kunieda-Alonso, S., Matsuoka, K., De Carvalho, M., and Zerbini, F. 2003. Purification and some properties of Papaya meleira virus, a novel virus infecting papayas in Brazil. Plant Pathol. 52:389-394.

Madroñero, J., Rodrigues, S. P., Antunes, T. F. S., Abreu, P. M. V., Ventura, J. A., Fernandes, A. A. R., and Fernandes, P. M. B. 2018. Transcriptome analysis provides insights into the delayed sticky disease symptoms in Carica papaya. Plant Cell Rep. 37:967-980.

Magaña-Álvarez, A., Vencioneck Dutra, J. C., Carneiro, T., Pérez-Brito, D., TapiaTussell, R., Ventura, J. A., Higuera-Ciapara, I., Fernandes, P. M. B., and Fernandes, A. A. R. 2016. Physical characteristics of the leaves and latex of papaya plants infected with the Papaya meleira virus. Int. J. Mol. Sci. 17:574.

Maurastoni, M., Sá-Antunes, T. F., Oliveira, S. A., Santos, A. M. C., Ventura, J. A., and Fernandes, P. M. B. 2020. A multiplex RT-PCR method to detect papaya meleira virus complex in adult pre-flowering plants. Arch. Virol. 165:1211-1214.

Meissner Filho, P., Lima Neto, F., de Oliveira, C., Santana, S., and Dantas, J. 2017. Avaliação da resistência de genótipos de mamoeiro ao vírus da meleira no Semiárido. Report No. 1809-5003. Page 21. Embrapa Mandioca e Fruticultura, Cruz das Almas, BA, Brazil.

Nakagawa, J., Takayama, Y., and Suzukama, Y. 1987. Exudação de látex pelo mamoeiro. Estudo de ocorrência em Teixeira de Freitas, BA. Pages 555-559 in: Congresso Brasileiro de Fruticultura, 9, Campinas. Anais, Campinas, SP, Brazil.

Pathania, N., Justo, V., Magdalita, P., de la Cueva, F., Herradura, L., Waje, A., Lobres, A., Cueto, A., Dillon, N., Vawdrey, L., Hucks, L., Chambers, D., Sun, G., and Cheesman, J. 2019. Integrated disease management strategies for the productive, profitable and sustainable production of high quality papaya fruit in the southern Philippines and Australia (FR2019-89). Australian Centre for International Agricultural Research (ACIAR), Canberra, Australia. https://www.aciar.gov.au/sites/default/files/project-pagedocs/final_report_hort.2012.113.pdf

Perez-Brito, D., Tapia-Tussell, R., Cortes-Velazquez, A., Quijano-Ramayo, A., Nexticapan-Garcez, A., and Martín-Mex, R. 2012. First report of papaya meleira virus (PMeV) in Mexico. Afr. J. Biotechnol. 11:13564-13570.

Perring, T. M., Gruenhagen, N. M., and Farrar, C. A. 1999. Management of plant viral diseases through chemical control of insect vectors. Annu. Rev. Entomol. 44:457-481

Quito-Avila, D. F., Alvarez, R. A., Ibarra, M. A., and Martin, R. R. 2015. Detection and partial genome sequence of a new umbra-like virus of papaya discovered in Ecuador. Eur. J. Plant Pathol. 143:199-204.

Rodrigues, C., Ventura, J., and Maffia, L. 1989. Distribuição e transmissão da meleira em pomares de mamão no Espírito Santo. Fitopatol. Bras. 14:118.

Rodrigues, S., Andrade, J., Ventura, J., Lindsey, G., and Fernandes, P. 2009. Papaya meleira virus is neither transmitted by infection at wound sites nor by the whitefly Trialeurodes variabilis. J. Plant Pathol. 91:87-91.

Rodrigues, S. P., Galvao, O. P., Andrade, J. S., Ventura, J. A., and Fernandes, P. M. B. 2005. Simplified molecular method for the diagnosis of Papaya meleira virus in papaya latex and tissues. Summa Phytopathol. 31:281-283.

Rodrigues, S. P., Ventura, J. A., Aguilar, C., Nakayasu, E. S., Almeida, I. C., Fernandes, P., and Zingali, R. B. 2011. Proteomic analysis of papaya (Carica papaya L.) displaying typical sticky disease symptoms. Proteomics 11:2592-2602.

Rodrigues, S. P., Ventura, J. A., Aguilar, C., Nakayasu, E. S., Choi, H., Sobreira, T. J. P., Nohara, L. L., Wermelinger, L. S., Almeida, I. C., Zingali, R. B., and
Fernandes, P. M. B. 2012. Label-free quantitative proteomics reveals differentially regulated proteins in the latex of sticky diseased Carica papaya L. plants. J. Proteomics 75:3191-3198.

Roossinck, M. J. 2013. Plant virus ecology. PLoS Pathog. 9:e1003304.

Sá Antunes, T. F. S., Amaral, R. J. V., Ventura, J. A., Godinho, M. T., Amaral J. G., Souza, F. O., Zerbini, P. A., Zerbini, F. M., and Fernandes, P. M. B. 2016. The dsRNA virus papaya meleira virus and an ssRNA virus are associated with papaya sticky disease. PLoS One 11:e0155240.

Soares, E., Werth, E. G., Madroñero, L. J., Ventura, J. A., Rodrigues, S. P., Hicks, L. M., and Fernandes, P. M. B. 2017. Label-free quantitative proteomic analysis of pre-flowering $\mathrm{PMeV}$-infected Carica papaya L. J. Proteomics 151:275-283.

Solomon, M., Belenghi, B., Delledonne, M., Menachem, E., and Levine, A. 1999. The involvement of cysteine proteases and protease inhibitor genes in the regulation of programmed cell death in plants. Plant Cell 11:431-443.

Sorel, M., Mooney, B., de Marchi, R., and Graciet, E. 2019. Ubiquitin/proteasome system in plant pathogen responses. Annu. Plant Rev. Online https://doi.org/ 10.1002/9781119312994.apr0665

Taliansky, M. E., and Robinson, D. J. 2003. Molecular biology of umbraviruses: phantom warriors. J. Gen. Virol. 84:1951-1960.

Tapia-Tussell, R., Magaña-Alvarez, A., Cortes-Velazquez, A., Itza-Kuk, G., Nexticapan-Garcez, A., Quijano-Ramayo, A., Martin-Mex, R., and PerezBrito, D. 2015. Seed transmission of Papaya meleira virus in papaya (Carica papaya) cv. Maradol. Plant Pathol. 64:272-275.

Varun, P., Ranade, S. A., and Saxena, S. 2017. A molecular insight into papaya leaf curl-a severe viral disease. Protoplasma 254:2055-2070.

Ventura, J. A., Costa, H., and da Silva Tatagiba, J. 2004. Papaya diseases and integrated control. Pages 201-268 in: Diseases of Fruits and Vegetables: Volume II. S. A. M. H. Navqi, ed. Springer, Dordrecht, The Netherlands.

Ventura, J. A., Costa, H., Tatagiba, J. S., Andrade, J. S., and Martins, D. S. 2003 Meleira do mamoeiro: Etiologia, sintomas e epidemiologia. Pages 267-276 in: Papaya Brasil: Qualidade do mamão para o mercado interno, Vitória-Espírito Santo, Brazil.

Ventura, J. A., Lima, I. M., Martins, M. V. V., Culik, M. P., and Costa, H. 2019 Impact and management of diseases in the propagation of fruit plants. Rev. Bras. Frutic. 41:e-647.

Verchot, J. 2016. Plant virus infection and the ubiquitin proteasome machinery: arms race along the endoplasmic reticulum. Viruses 8:314.

Vidal, C., Nascimento, A., and Habibe, T. 2003. Transmissão do vírus da meleira do mamoeiro por insetos. Pages 612-615 in: Papaya Brasil: Qualidade do Mamão Para o Mercado Interno, Vitória, Espírito Santo, Brazil.

Whitfield, A. E., Falk, B. W., and Rotenberg, D. 2015. Insect vector-mediated transmission of plant viruses. Virology 479-480:278-289.

Wu, Z., Mo, C., Zhang, S., and Li, H. 2018. Characterization of Papaya ringspot virus isolates infecting transgenic papaya 'Huanong No. 1'in South China. Sci. Rep. 8:8206.

Xia, X.-J., Zhou, Y.-H., Shi, K., Zhou, J., Foyer, C. H., and Yu, J.-Q. 2015. Interplay between reactive oxygen species and hormones in the control of plant development and stress tolerance. J. Exp. Bot. 66:2839-2856.

Zamudio-Moreno, E., Ramirez-Prado, J., Moreno-Valenzuela, O., and LopezOchoa, L. 2015. Early diagnosis of a Mexican variant of Papaya meleira virus (PMeV-Mx) by RT-PCR. Genet. Mol. Res. 14:1145-1154.

Zhang, R., Hisano, S., Tani, A., Kondo, H., Kanematsu, S., and Suzuki, N. 2016. A capsidless ssRNA virus hosted by an unrelated dsRNA virus. Nat. Microbiol. 1: 15001 . 